\title{
SPATIAL DIVERSITY OF TOURIST FUNCTION DEVELOPMENT: THE MUNICIPALITIES OF POLAND'S WEST POMERANIA PROVINCE
}

Jacek Borzyszkowski, Mirosław Marczak, Patrycjusz Zarębski

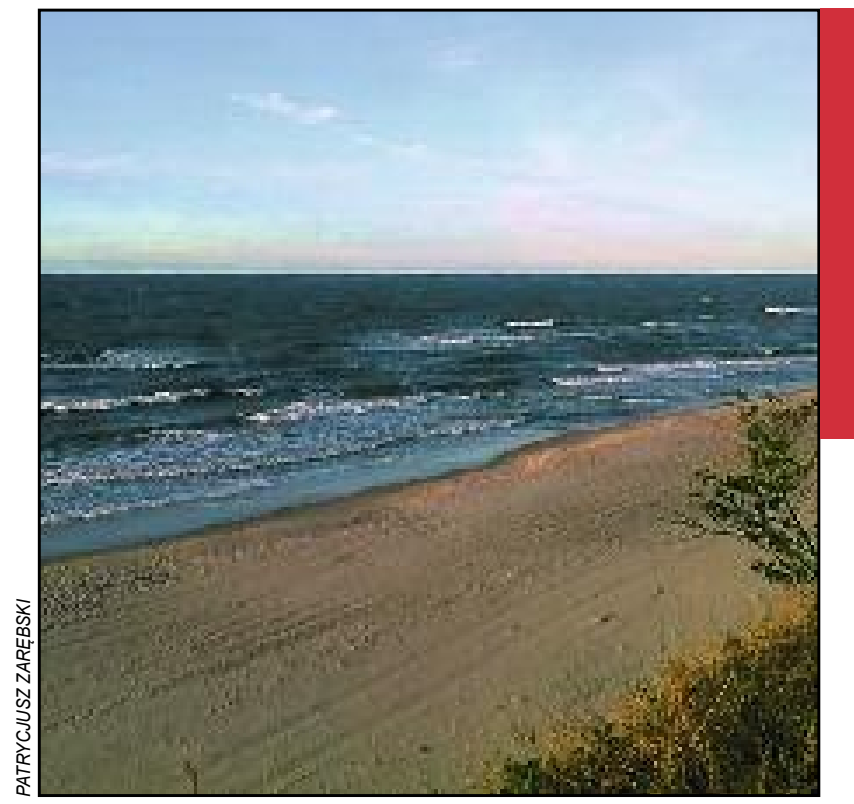

Seaside in Sarbinowo, West Pomerania Province. 


\title{
Spatial diversity of tourist function development: the municipalities of Poland's West Pomerania province
}

\author{
DOI: http://dx.doi.org /10.3986/AGS.769 \\ UDC: $911.3: 338.48(438.52)$ \\ COBISS: 1.01
}

\begin{abstract}
This article examines the spatial diversity of tourist function development using the example of one of Poland's sixteen main administrative regions: the West Pomerania Province (Polish: Województwo zachodniopomorskie). The analysis was carried out based on the values of the Defert tourist function index, which is one of the basic indexes used in tourism geography. The analysis demonstrated significant differences between the individual municipalities in the region examined. This confirms the assumption that seaside municipalities have the highest tourist function development.
\end{abstract}

KEY WORDS: tourist function, municipality, province, lodging places, population, Poland

This article was submitted for publication on March $14^{\text {th }}, 2014$.

\section{ADDRESSES:}

Jacek Borzyszkowski, Ph.D.

Tourism department, Faculty of economics, Koszalin University of technology

Ul. E. Kwiatkowskiego 6E, 75-343 Koszalin, Poland

E-mail: jacbo@wp.pl

Mirosław Marczak, Ph.D.

Tourism department, Faculty of economics, Koszalin University of technology

Ul. E. Kwiatkowskiego 6E, 75-343 Koszalin, Poland

E-mail: miromilan@wp.pl

Patrycjusz Zarębski, Ph.D.

Department of rural economics, Institute of rural and agricultural development in Warsaw, Polish academy of sciences

Ul. Nowy Świat 72, 00-330 Warszawa, Poland

E-mail: patrycjusz.zarebski@gmail.com 


\section{Introduction}

At present, a number of various methods (Crouch and Ritchie 1995; Dwyer et al. 2000; Heath 2002) can be indicated which define the competitiveness of a destination. This is possible among others trough a determination of the development degree of the tourist function of a given destination. Literature provides a number of different methods (e.g. Aubert et al. 2013; Defert 1972; Kowalczyk 2002; Warszyşska 1985) that allow a fairly precise determination of the fact whether a given region possesses a properly developed tourist function.

The use of appropriate indexes is one of the ways to determine this level. In the geography of tourism and tourism economics, there is a whole spectrum of this type of measures including tourist comfort index, the concentration index, attractiveness index (Coccossis and Parpairis 2000), overall tourism intensity index, foreign tourism intensity index (Soybali 2005). The advantage being the result of the use of appropriate indexes follows the fact that they are actually reliable on one hand and they are objective on the other hand. However, it needs to be emphasized that the expression »index « may have different meanings. According to Smith $(2010,132)$, the »index refers to the combination of two or more variables into a single measure to provide a succinct indication of some phenomenon ".

The chief purpose of this article is an attempt to assess the development level of the tourist function of the individual communes in West Pomerania Province (in Polish Województwo zachodniopomorskie), which is one of the 16 main administrative regions in Poland. The analysis carried out was based on one of those indexes that are most frequently used in the geography of tourism, i.e. the Defert tourist function index (DTFI). The intention of the authors was also to indicate spatial differences in the development level of the tourist function in the individual areas of the province, i.e. seaside, lakeland and the remaining areas. It is worth noting that other natural values (e.g. geodiversity, landscape, zoological and botanical values) and cultural values are very important in analysis of the spatial diversity of development of the tourist function. However, it can be accepted that natural values analyzed (hydrological natural features) are one of the important factor in tourist function diversity (Szwichtenberg 1995).

\section{Literature review}

Tourist function is understood as a socioeconomic activity pursued by a given area and its inhabitants, aimed at tourist services (Kowalczyk 2002). The scale and nature of the tourist function can be presented by means of various measures and numerous qualitative features (Durydiwka 2013).

In the literature, the development of tourist function is usually determined by measures based on the size of accommodation, tourist traffic, the number of employees in tourist services or income from tourism (Durydiwka 2013). Some of those refer to simple formulae (ones that often include two variables), while others present more extended components that are based e.g. on accepted weights (e.g. the municipal tourist index, which is related to 5 quantities i.e. attractions: $20 \%$; dominant tourist products: $25 \%$; tourist information office: $5 \%$; turnover of accomodations: $45 \%$ and tourism tax: 5\% (Aubert et al. 2013).

As Jreat $(2004,161)$ states, »among the several methods proposed by scholars to measure the relative importance of tourism, the one that has gained most acceptance is Defert's tourist function index «. Defert's tourist function index (DTFI) compares the number of tourist beds available in a destination to the total number of residents, or hosts in the region' (Boniface and Cooper 1987) and is expressed as (Defert 1972, 10):

$$
\mathrm{DTFI}-\mathrm{T}(\mathrm{f})=\frac{\text { Bed capacity } \times 100}{\text { Resident population }}
$$

The abovementioned index is one of the most frequently used ones when determining the development degree of the tourist function of a given destination (Lasanta et al. 2007; Smith 1995). It is also worth to indicate the purpose which was pursued when Defert created the index analyzed. His goal in creation this function was to develop a single measure that reflects the relative magnitude of tourism in a local economy (Smith 2010). 
The index presented above possesses a fairly wide application. While initially applied to towns and cities, the index has also been used at national and regional level (Jreat 2004).

The index is characterized by a fundamental advantage, i.e. an ease of obtaining data which required for its calculation. In the majority of countries, information concerning the bed capacity and resident population can be obtained among others from statistical yearbooks or other studies of this type. On the other hand, it is advisable to indicate a number of imperfections. Firstly, the index does not take into account certain values which are not usually presented in tourist statistics (the so-called »the second homes « or »lodging places offered by "acquaintances and friends«) (Zelenka and Pásková 2012). On the other hand, studies concerning the Defert index for individual towns and regions occur in literature taking into consideration »second homes « (Opačić and Mikačić 2009). What is more, its application is definitely more useful and proper when determining the level of the tourist function of spatial units with a relatively small number of permanent residents or ones which are small in terms of the number of the residents that live in localities (communes). The index is focused on localities (communes) with lower values of the denominator, i.e. the number of permanent residents (Szwichtenberg and Borzyszkowski 2000). This is confirmed by Soybali $(2005,88)$, according to whom »number of resident population plays an important role and while the DTFI value of densely populated larger regions or provinces could indicate smaller values despite the large number of beds, regions or provinces where the number of resident population lesser and more polarised may indicate significantly higher DTFI values despite smaller bed capacity«. The author emphasizes that the value of the index is clearly dependent on the number of residents, and hence it may accept relatively low values in regions with high population. He mentions regions in Turkey as an example, where in the majority of cases the values were below 1.0 (apart from the following regions: Mediterranean and Aegean) (Soybali 2005). There is a similar situation in the case of large cities, which possess a significant number of lodging facilities and places. This is confirmed by Muska and Bite $(2011,225)$ among others, according to whom "as Riga region concentrates one third of the permanent residents of the country and more than $40 \%$ beds of tourist accommodation establishments, the value of Defert's function is not significantly different (1,8 in 2009) from the average indicators of Latvia (1,4 in 2009)《.

A review of scientific literature in the scope of the index analysed clearly confirms its wide application. Individual researchers provide not so much a theoretical DTFI analysis but they primarily indicate its practical applications in various destinations. Hence, the results obtained allow a proper and objective assessment concerning the development level of the tourist function of individual destinations. For example Jreat (2004) provides the values of the Defert index for individual 12 districts in India. The average value was almost 5.12. It appears that only two districts (Chamba and Kullu) achieved a value that was above the average: 6.88 and 43.79 respectively. Jreat (2004) also analyzed the value for 29 selected Indian towns. In this case, these values fluctuated from 0.2 (Baddi) to 180.17 (Manali). Lundgren (2006) examined the values of the index for Baltic ports and demonstrated huge disproportions between individual cases. The highest value was observed for Visby (358.94) and the lowest one for St. Petersburg (3.40). A number of ports (those significant ones) possessed relatively low values, e.g. Copenhagen (10.9) or Helsinki (10.8). The research carried out by Bănică and Camară (2011) on a group of 215 small towns in Romania (below 20.000 residents) indicate that a significant majority of them have a relatively poorly developed tourist function (based on the value of the Defert index). Nevertheless there can be identified 30 localities including or overlapping officially recognized tourist resorts ( 23 of national and 7 of local importance). This status is reflected by the tourist function index which varies between $0 \%$ (many of these towns have no lodging capacities or tourist activities) and $260 \%$. Generally speaking, relatively high values (or higher than average ones) are observed in strictly tourist regions. The example of three administrative units that are included in the »Tirol-Südtirol-Trentino « Euroregion serves to confirm this assumption. In the year 2009, the value for Trentino was 31.6; for the South Tyrol: 43.7; and for Tyrol: 38.5; for the whole of Italy, it was 7.6; and for Austria: 11.5 (Brida and Giuliani 2012).

In the majority of cases the analyses carried out concern clearly defined spatial units, e.g. administrative units (towns and communes). Furthermore, literature includes studies that refer to specified parts of individual administrative units. For example, the value for the Florence municipality is 6.37; for the historical center of this town: 15.30 (for Venice, 7.30 and 15.00 respectively) (van der Borg et al. 1996). 


\section{Methodology}

\subsection{Description of study area}

West Pomerania Province is one of the major tourist regions in Poland. Taking into consideration the basic data connected with tourist movement, an essential role is to be observed of the area examined in national tourism, i.e.:

- the number of foreign tourists in the year 2012: $1.53 \mathrm{~m}$ ( $4^{\text {th }}$ position in the country) (Bartoszewicz and Skalska 2013, 35),

- the number of home tourists in the year 2012:3.1 $\mathrm{m}$ ( $6^{\text {th }}$ position in the state) (Krajowe i zagraniczne ... 2013,6),

- the number of tourist lodging facilities in the year 2012: 1,219 ( $3^{\text {rd }}$ position in the state) (Turystyka ...2013, 84 and 86),

- the number of lodging places in the year 2012: 119,967 ( $1^{\text {st }}$ position in the state) (Turystyka ...2013, 84 and 86 )

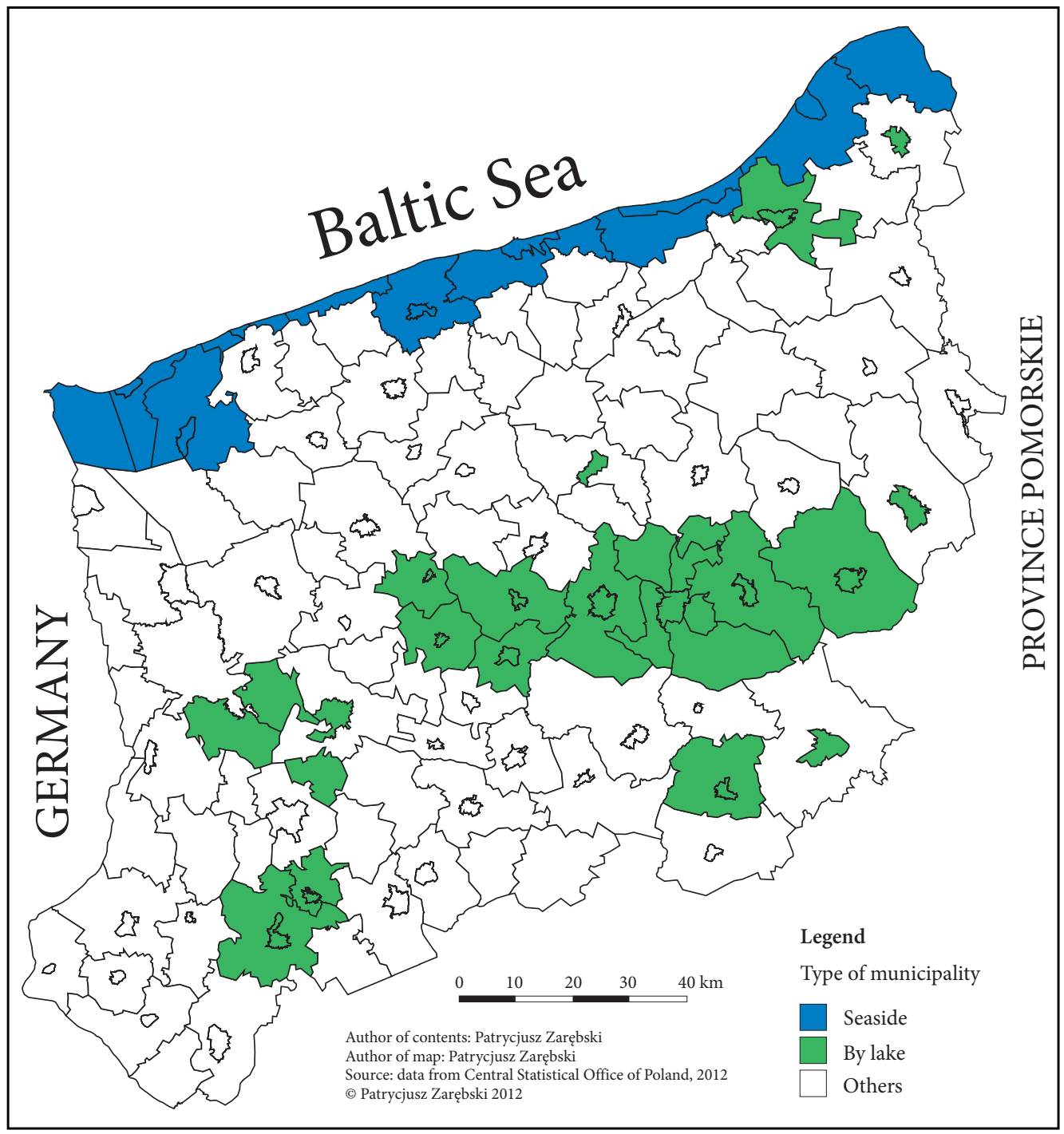

Figure 1: The nature of communities due to natural values. 
The communes of West Pomerania Province can be classified among others considering basic natural values, which often constitute the base of the development of tourism. In the article, the following criteria were accepted of the delimitation of communes, and the following units were distinguished:

- seaside units: those that with an access to the shoreline of the Baltic Sea,

- lakeland units: those that possess the index of lake area on a level greater than 5\% (Instytut Turystyki 2014),

- other units which do not meet the abovementioned criteria.

Taking into consideration the possession of natural values, which constitute the base for the development of the tourist function, the communes of the province examined are characterized by a fairly high diversification (Figure 1). 14 communes possess an access to the Baltic Sea (12\% of all the communes), ones that are situated in the north part of the province. A high percentage of the lake area occurs in 22 communes (19\% of all the communes), ones which are situated mainly on the area of lake districts. In a general listing, communes with natural values that are over the average and that are favourable for the development of tourism constitute $31 \%$ of all the communes.

To sum up the current discussion, it is to be stated that the information and data obtained (Figure 1) confirm the fact that the region analysed is characterized by a significant natural diversity. As a consequence, this results in a diversification of tourist attraction. It can be assumed a priori that there are similar differences in the scope of the development level of the tourist function of individual administrative units (communes).

\subsection{Methods}

In the present study, the analysis makes use of a division of the values of the index examined accepted by Boyer (1972) and Pearce (1995). Authors grouped tourism regions in six categories according to their DTFI values as follows:

- > 500 recent 'hypertouristic' resort,

- 100-500 large tourist resort,

- 40-100 predominantly tourist commune,

- 10-40 communes with an important but not predominant tourist activity,

- 4-10 little tourist activity or tourist function 'submerged' in other urban functions,

- <4 practically no tourist activity.

As stated by Pearce $(1995,84)$ »value of 100 indicates that the number of tourists would equal the number of local residents, assuming all beds available were being used «. The literature includes various interpretations of the values provided above. According to some researchers, the value of the index over 100 demonstrates a well developed tourist function (Kowalczyk 2002; Szromek 2007), while other researchers reduce this value (e.g. for Poland) to 50 (Warszyşska 1985; Żek 2008).

The data concerning the number of lodging places and the number of population was obtained from the Central Statistical Office (Główny Urząd Statystyczny 2014). The percentage of the area of lakes in the communes was determined based on the data obtained from the "Commune database « from the Institute of tourism in Warsaw. A spatial visualization of the results obtained in the form of maps was prepared based on standard graphical tools which are available in the Windows environment and the geostatistics portal of the Central statistical office.

In the study, the following research hypothesis was accepted: the development level of the tourist function is clearly diversified depending on the nature of communes (and thereby the type of natural values that occur on their area). In the study, a division of the communes into seaside, lakeland and other was accepted.

\section{Results and discussion}

The region examined is quite strongly spatially diversified with regard to the development of the tourist function (Table 1, Figure 2). $83 \%$ of all the lodging places in the province with $11 \%$ of population potential are concentrated in the seaside strip. This gives the values of the tourist function index for these communes on the level of DTFI $=52.4$. This causes significant disproportions in the development of tourism in the area examined. For comparison, in the lakeland communes with a high index of the lake area, there are only $5 \%$ of the lodging places of the province with relatively low values of the DTFI index $=2$. 
The highest values of the DTFI index (100-500) were observed in some seaside communes (e.g. Mielno, Rewal). This proves a very high share of tourism in the economic system of the commune (cf. Table 1). In the case of these units, tourism is the main factor in the formation of the local economy. A slightly lower significance of tourism in the economy (DTFI index 40-100) was observed in such communes as Darłowo and Międzyzdroje. A coexistence of tourism with other important sectors of economy was observed in the following towns: Kołobrzeg, Darłowo, Świnoujście and the following communes: Złocieniec, Trzebiatów and Nowe Warpno. In this case, tourism is developing alongside with activities connected with fishery, food processing or the development of industry. Hence, these communes did not obtain any high values of the index examined. Moreover, in some seaside communes, a relatively low DTFI value resulted from a fairly high number of residents (this situation occurs in Kołobrzeg town, which is resided by ca. 50 thousand of residents; nota bene, this town is the largest health-resort in Poland!).

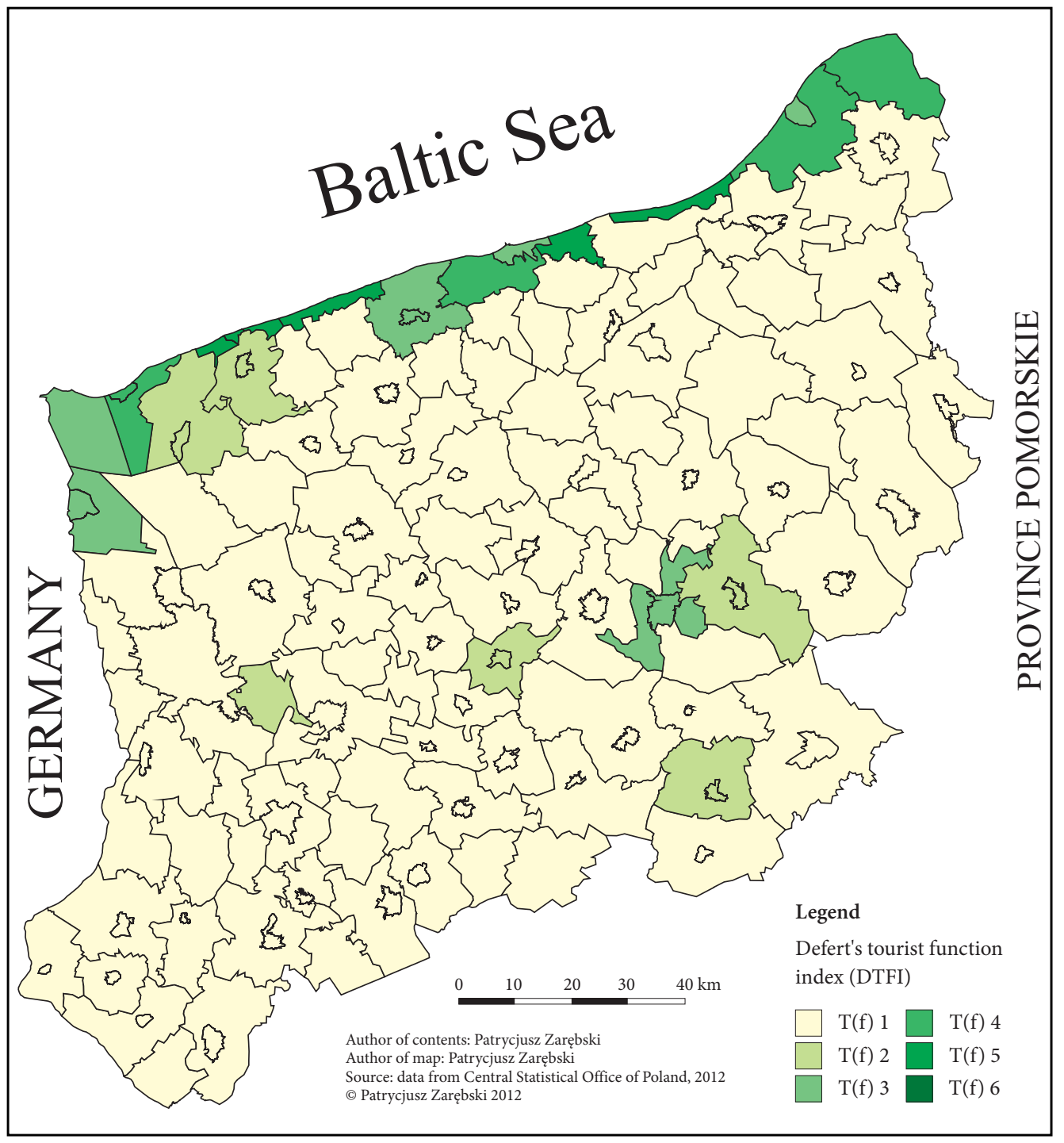

Figure 2: Spatial differentiation of Defert's tourist function index (DTFI). 
Jacek Borzyszkowski, Mirosław Marczak, Patrycjusz Zarębski, Spatial diversity of tourist function development: ...

Table 1: Value of the Defert index for communes in West Pomerania Province $(N=114)$.

\begin{tabular}{|c|c|c|c|c|c|c|c|c|}
\hline \multirow[t]{2}{*}{ Number } & \multicolumn{2}{|c|}{ Value of the Defert index } & \multicolumn{2}{|c|}{ Seaside communes } & \multicolumn{2}{|c|}{ Lakeland communes } & \multicolumn{2}{|c|}{ Other communes } \\
\hline & Range & Group & Number & (in \%) & Number & (in \%) & Number & (in \%) \\
\hline 1. & $>500$ & $T(f) 6$ & - & - & - & - & - & - \\
\hline 2. & $100--500$ & $T(f) 5$ & 4 & 28,6 & - & - & - & - \\
\hline 3. & $40-100$ & $\mathrm{~T}(\mathrm{f}) 4$ & 4 & 28,6 & - & - & - & - \\
\hline 4. & $10-40$ & $T(f) 3$ & 4 & 28,6 & 1 & 4,5 & 1 & 1,3 \\
\hline 5. & $4-10$ & $T(f) 2$ & 1 & 7,1 & 4 & 18,2 & 1 & 1,3 \\
\hline 6. & $<4$ & $T(f) 1$ & 1 & 7,1 & 17 & 77,3 & 76 & 97,4 \\
\hline 7. & \multicolumn{2}{|c|}{ Total } & 14 & 100 & 22 & 100 & 78 & 100 \\
\hline
\end{tabular}

The analysis carried out demonstrated a spatial diversity of the area examined with respect to the index analysed. Thereby, the research hypothesis accepted in the article was confirmed. The seaside communes can be recognized as units with definitely the highest development degree of the tourist function. It is worth to mention that their advantage over the lake district units and other units is quite high.

The phenomenon above is confirmed among others by the research carried out by Mikačić (2007), from which it results that seaside regions in Croatia accept definitely the highest values of the Defert index: the average value was 94.0 (taking into consideration »second homes«). As many as $80 \%$ of accommodation places of the whole state are situated on the Croatian coast. The values for the inland part averaged 11.0 (Mikačić 2007). The example of the inland part of the Istria country demonstrates that the values for individual municipalities and towns fluctuated from 3.32 to 53.76 (Vojnovic and Knezevic 2013, 219). Papapavlou-Ioakeimidou et al. (2006) accept a similar opinion. They demonstrated on the example of the Greek coast that communities with the highest value of the index examined are mainly located along coastal zones, particularly in the small peninsulas of Kassandra and Sithonia, in western and southern Chalkidiki. Quite diversified values were obtained in the individual provinces of the Italian Sicily: extreme values amounted to 6.40 (Caltanissetta) and 54.88 (Messina). The average value for the whole island was 28.74 (Giacalone et al. 2005, 160).

The analysis of the spatial diversity carried out in this article confirms the results of the research and assumptions by Mikačić (2007), Vojnovic and Knezevic (2013), Papapavlou-Ioakeimidou et al. (2006) and Giacalone et al. (2005). However, they are so essential and important that an analysis was carried out of units located outside of the main tourist regions of Europe. This means that no regions or other administrative units situated in the basin of the Mediterranean Sea were covered by the research. The analysis was related to a region situated in the direct neighbourhood of the Baltic Sea, which is characterized by a definitely smaller attractiveness (for instance considering the climate) than that of the Mediterranean Sea. Nonetheless, it became evident that even in this case the seaside units are characterized by a definitely higher level of the development of the tourist function than the other units.

\section{Conclusion}

The analysis of the spatial diversity of the development degree of the tourist function carried in the article demonstrated significant disproportions in the range of the values of the Defert index in the area examined. This is among others the result of the diversity of the region examined, chiefly as regards the possession of natural values. The division accepted in the article of 114 communes into individual types of units, i.e. seaside, lakeland and others as well as the analysis carried out of these units regarding the development degree of the tourist function allowed the author to propose several essential conclusions, i.e.:

- West Pomerania Province is diversified owing to its natural values (the Baltic Sea, lakes) and so is the character of the individual administrative units (seaside, lakeland, other). The main areas of the concentration of these values occur in the northern communes of the province and also in those communes that are situated in the area of lake districts in the southern and eastern parts of the province.

- The character of the natural values analysed determines the development of the tourist function in the province. As a result of the analysis, the highest development of the tourist function measured with the Defert index was observed in the seaside communes. The lakeland communes possess a relatively lower level of development. 


\section{References}

Aubert, A., Jónás-Berki, M., Marton, G. 2013: Tourism index as an indicator of the intensity of tourism. Acta geographica Slovenica 53-2. DOI: http://dx.doi.org/10.3986/AGS53205

Bănică, A., Camară, G. 2011: Accessibility and tourist function development of the Romanian small towns. Geo journal of tourism and geosites 1-7.

Bartoszewicz, W., Skalska, T. 2013: Zagraniczna turystyka przyjazdowa do Polski w 2012 roku, Ministerstwo Sportu i Turystyki, Instytut Turystyki. Warszawa. Internet: https:/d1dmfej9n5lgmh.cloudfront.net/ msport/article_attachments/attachments/47066/original/Zagraniczna_turystyka_przyjazdowa_do_ Polski_w_2012_roku.pdf?1375438064 (9.12.2013).

Boniface, B. G., Cooper, C. P. 1987: The geography of travel and tourism. London.

Brida, J. G., Giuliani, D. 2012: Empirical assessment of the tourism-led growth hypothesis: the case of the »Tirol-Südtirol-Trentino« Europaregion. DISA working paper 2. Trento.

Boyer, M. 1972: Le tourisme. Paris.

Coccossis, H., Parpairis, A. 2000: Tourism and the environment: some observations on the concept of carrying capacity. Dordrecht.

Crouch, G. I., Ritchie, J.R. B. 1995: Destination competitiveness and the role of the tourism enterprise. Proceedings of the fourth annual world business congress. Istanbul.

Defert, P. 1972: Le tourisme et les activites touristique. Essay d'integration. CET - Les Cahiers du tourisme 19.

Durydiwka, M. 2013: Tourist function in rural areas of Poland. Spacial diversity and changing trends. Miscellanea geographica - regional studies on development 17-3. DOI: http://dx.doi.org/10.2478/ v10288-012-0041-2

Dwyer, L., Forsyth, P., Rao, P. 2000: The price competitiveness of travel and tourism: a comparison of 19 destinations. Tourism management 21-1. DOI: http://dx.doi.org/10.1016/S0261-5177(99)00081-3

Giacalone, M., La Tona, L., Marino, C. 2005: Sustainability in the receptive - tourist field in Sicily. Roma. Internet: http://old.sis-statistica.org/files/pdf/atti/CIMe0905p159-162.pdf(6.12. 2013).

Główny Urząd Statystyczny, 2014. Internet: http://www.stat.gov.pl (4. 1.2014).

Heath, E. 2002: Towards a model to enhance destination competitiveness: a Southern African perspective. Journal of hospitality and tourism management 10-2.

Instytut Turystyki, 2014. Internet: http://www.intur.com.pl (5.1.2014).

Jreat, M. 2004: Tourism in Himachal Pradesh. New Delhi.

Kowalczyk, A. 2002: Geografia turyzmu. Warszawa.

Krajowe i zagraniczne wyjazdy Polaków w 2012 roku. Internet: https://d1dmfej9n5lgmh.cloudfront.net/ msport/article_attachments/attachments/42235/original/Wyj_Pol_2012.pdf?1365422013 (7.12.2013).

Lasanta, T., Laguna, M., Vicente-Serrano, S. M. 2007: Do tourism-based ski resorts contribute to the homogeneous development of the Mediterranean mountains? A case study in the Central Spanish Pyrenees. Tourism management 28. DOI: http://dx.doi.org/10.1016/j.tourman.2007.01.003

Lundgren, J. O. 2006: Spatial and evolutionary characteristics of Baltic Sea cruising: a historic-geographical overview. King's Lynn.

Mikačić, V. 2007: Utjecaj rezidencijalnog turizma na primorski prostor Hrvatske. Zbornik radova Četvrtog hrvatskog geografskog kongresa. Zagreb.

Muska, A., Bite, L. 2011: Evaluation of the development of tourist accommodation in the regions of Latvia. European integration studies 5.

Opačić, V. T., Mikačić, V. 2009: Second home phenomenon and tourism in the Croatian littoral - two pretenders for the same space? TOURISM - an international interdisciplinary journal 57-2.

Papapavlou-Ioakeimidou, S., Rodolakis, N., Kalfakakou, R. 2006: Spatial structure of tourist supply and relations between sub-regions: a case study in a coastal region, Greece. Internet: http://www-sre.wu-wien.ac.at/ ersa/ersaconfs/ersa06/papers/560.pdf (1.12.2013).

Pearce, D. 1995: Tourism today, a geographical analysis. London.

Smith, S. L. J. 1995: Tourism analysis. A handbook. Essex.

Smith, S. L. J. 2010: Practical tourism research. Cambridge.

Soybali, H.H. 2005: Temporal and spatial aspects of tourism in Turkey. Bournemouth University, Bournemouth.

Szromek, A. 2007: Wskaźniki ilościowe w ocenie sprawności operacyjnej sanatoriów. Gliwice. 
Szwichtenberg, A. 1995: Gospodarka turystyczna w okresie przejściowym. Koszalin.

Szwichtenberg, A., Borzyszkowski, J. 2000: Dyskusja nad miernikami funkcji turystycznej miejscowości. Problemy turystyki 1-2.

Turystyka w 2012 r. Główny urząd statystyczny 2013. Internet: http://www.stat.gov.pl/cps/rde/xbcr/gus/ KTS_turystyka_w_2012.pdf (4.12.2013).

Warszyşska, J. 1985: Funkcja turystyczna Karpat polskich. Folia geographica, series geographica-oeconomica 18.

van der Borg, J., Costa, P., Gotti, G. 1996: Tourism in European heritage cities. Annals of tourism research 23-2. Vojnovic, N., Knezevic, R. 2013: Ekonomic and tourism indicators as a means of monitoring sustainable tourist: the case of inland Istria. UTMS journal of economics 4-2.

Zelenka, J., Pásková, M. 2012: Výkladový slovník cestovního ruchu. Praha.

Żek, M. 2008: Funkcja turystyczna obszaru nadbużaşskiego. Turystyka i hotelarstwo 14. 